\title{
Ortadoğu'da Kayıp Yüzyılın Son Halkası: Arap İsyanları Sürecinde Kurumların Belirleyici Rolü ${ }^{1}$
}

\author{
Tahsin Yamak ${ }^{2}$ \\ Emre Saygın ${ }^{3}$
}

Ortadoğu'da Kayıp Yüzyılın Son Halkası: Arap İsyanları Sürecinde Kurumların Belirleyici Rolü

Öz

Ortadoğu, imparatorlukların dağılmasından Birinci Dünya Savaşı ertesindeki paylaşım sürecine kadar her anlamda müdahaleye maruz kalmış bir coğrafyadır. Sonraki dönemde ise yapay sınırlar, mozaik toplumlar ve baskıcı yönetimler nedeniyle birlik ve bütünlüğünü sağlayamamış istikrarsız bir bölge olarak görünmektedir. Bu sürecin son halkasını oluşturan "Arap İsyanları" sosyo-ekonomik nedenler, yönetimde katılımcılık ve meşruiyet sorunları, çoklu kimliklerin yönetimlerce manipüle edilmesi, özgürlüklerin sınırlandırılması gibi değişkenler etrafında gerekçelendirilmekte ve devrim, iç savaş veya yönetim değişiklikleri gibi sonuçlar üzerinden okunmaktadır. Bu çalışma, Ortadoğu'daki yönetişim boşluğunun Arap isyanları sürecinin gelişimini işaret ettiği hipotezine dayanmaktadır. Nicel verilere dayanan kurumsal göstergeler etrafında karşılaştırmalı ve dinamik olarak yürütülen analiz sonucunda, Arap İsyanları sürecinin iç ve dış aktörler açısından sürpriz olmadığı, ancak kurumsal değişim için uygun koşulları da sağlamadığı anlaşılmaktadır.

Anahtar Kelimeler: Ortadoğu, Arap İsyanları, Kurumlar, Kurumsal Yapı, Kurumsal Değişim
The Last Ring of the Lost Century in the Middle East: Determinants Role of Institutions in Arap Uprising Process

\section{Abstract}

The Middle East is a geography that has been exposed to intervention in every sense from the collapse of the empires to the process of sharing after the First World War. In the following period, it seems to be an unstable region that did not provide unity and integrity due to artificial borders, mosaic societies and repressive governments. The "Arab Uprising" that constitute the last ring of this process are expressed around variables such as socioeconomic reasons, participation and legitimacy problems in administration, manipulation of multiple identities in the administration, limitation of freedoms, and read over on results such as revolution, civil war or management changes. This study is based on the hypothesis that governance gap in the Middle East indicates the evolution of the Arab Uprising process. As a result of comparative and dynamic analysis of institutional indicators based on quantitative data, it is understood that the Arab Uprising process is not surprising in terms of internal and external actors, but does not provide suitable conditions for institutional change.

Keywords: The Middle East, Arab Uprising, Institutions, Institutional Structure, Institutional Change

\section{Giriş}

Ortadoğu, bölge-içi çatışmaların yoğun olarak yaşandığı, otoriter-baskıcı politik sistemlerin varlığını sürdürdüğü ve doğal kaynak merkezli ekonomik yapının hâkim olduğu istikrarsız bir coğrafya olarak değerlendirilmekte ve bu nedenle bölgede toplumsal reaksiyonların ortaya çıkma potansiyeli süreklilik arz etmektedir. Bu bağlamda, Ortadoğu'nun sahip olduğu jeostratejik özelliklerin, avantajlarını aşan handikaplarının ağır basması sonucunda, kayıp yüzyıl olarak isimlendirdiğimiz uzunca bir zamandan bu yana süregelen ve bazen ülkeler özelinde, bazen ise bölge genelinde olumsuz etkiler doğuran toplumsal olaylar silsilesi, kendisini son olarak Arap isyanları olarak adlandırılan sosyo-ekonomik sorunlar bütünü olarak göstermiştir.

\footnotetext{
${ }^{1}$ Bu çalışma, 11-13 Ekim 2016'da, Sakarya Üniversitesi'nin ev sahipliğinde düzenlenen III. Ortadoğu'da Siyaset ve Toplum Kongresi'nde sunulan “Ortadoğu'da Kayıp Yüzyılın Son Halkası: Arap İsyanları Sürecinin Kurumsal Ekonomi Politiği” başıklı tebliğin genişletilmiş ve güncellenmiş halidir.

${ }^{2}$ Dr., Bağımsız Akademisyen, tahsinyamak@gmail.com

${ }^{3}$ Dr., Bağımsız Akademisyen, sayginemre@gmail.com
} 
Bu kriz sürecinin ortaya çıkış sebeplerine ilişkin, makroekonomik parametreleri ve ekonomik gelişme/kalkınma göstergelerini esas alan birçok sosyo-ekonomik değerlendirmeler yapılmakta ise de, demokrasi bağlamında yürütülen araştırmalar dışında, konuya yönetişim göstergeleri ve yeni kurumsal iktisat ekolü perspektifinden açıklama getiren sınırlı sayıda çalışma bulunmaktadir.

İşte bu çalışmada, Dünya Bankası, Uluslararası Finans Kurumu (IFC), Fraser Enstitüsü, Dünya Ekonomik Forumu, Uluslararası Şeffafık Örgütü (Transperancy International), Özgürlük Evi'nin (Freedom House), Heritage Vakfı, Mülkiyet Hakları Birliği'nin (Property Rights Alliance), Ekonomist Dergisi (The Economist) gibi çeşitli uluslararası kuruluşlar tarafından üretilen ve gerek kapsamlı yönetişim ve ekonomik özgürlük göstergelerini içeren gerekse münferiden belirli bir kurumsal göstergeye odaklanan endeksler vasıtasıyla, genel olarak Ortadoğu bölgesindeki yönetişim boşluğu ekseninde, Arap isyanlarının büyük çapta yaşandığı Tunus, Mısır, Libya, Yemen, Bahreyn ve Suriye'de; formel ve enformel kurumların kapsayıcılığı/etkinliği, piyasaya yönelik düzenlemelerin kalitesi ve kaynakların yönetimi, iş dünyası- sivil toplum-politika yapıcılar arasındaki etkileşimler ve yolsuzlukla mücadele, hukukun üstünlüğü ve sözleşmelerin uygulanabilirliği ile mülkiyet hakları güvencesi, ifade özgürlügü ve hesap verilebilirlik, demokratik katılım ve siyasetin finansmanı, politik istikrar ve şiddetsizlik/şiddet yokluğu temaları etrafında siyasal, ekonomik ve sosyal kurumlara ilişkin nicel verilerin analitik bir bakış açısı ile incelenmesi suretiyle "Arap isyanları süreci Ortadoğu için sürpriz bir durum mu, kaçınılmaz bir son mu?" sorusuna cevap verilmesi hedeflenmektedir.

\section{Ortadoğu'nun Kayıp Yüzyılı ve Arap İsyanları}

Asya, Avrupa ve Afrika kıtalarının kesişme noktasında bulunan Ortadoğu, birçok kadim medeniyetin doğduğu ve/veya geliştiği, stratejik önemi haiz bir coğrafyadır. Bölgenin sahip olduğu sosyal, ekonomik ve kültürel zenginlikler, Osmanlı İmparatorluğu'nun otoritesinin zayıflamaya başladığı 18 inci ve 19 uncu yüzyıldan itibaren, Ortadoğu'nun müdahaleye ve manipülasyona açık dezavantajlı yönleri olarak belirginleşmiş, bölge halkları arasındaki birlik duygusunun aşınması suretiyle de ayrılıkların derinleşmesine yol açmıştır (Dursun, 2005: 1235; Sakin ve Deveci, 2011: 285-286).

Diğer taraftan, Avrupa kıtasında hızla gelişen sanayileşme sürecinin bir sonucu olarak enerji talebinin genişlemesi, küresel enerji rezervlerinin önemli bir kısmına sahip olan Ortadoğu'ya olan ilgiyi arttırmış; diğer bir deyişle ekonomik ilişkilerde petrolün ön plana çıktığı 20 nci yüzyıl başlarından itibaren Ortadoğu önemli bir çekim alanı haline gelmiştir. Enerji talebinin dış politika ve güvenlik siyasetlerinin oluşturulmasında da belirleyici rol oynadığı bu süreç, oldukça eski ticari bağlara ve kültürel etkileşimlere sahip olan Avrupa - Ortadoğu ilişkilerinin form değiştirmesine yol açmış ve sömürgecilik döneminin başlamasıyla neticelenmiştir (Rafeq, 2005: 287; Ayhan, 2006: 86).

Bu dönem boyunca neredeyse her alanda dış müdahaleye maruz kalan Ortadoğu, 20 nci yüzyılın ortalarına doğru yapay sınırlarla ayrılmış, parçalı toplumsal yapıları haiz, otoriter/baskıcı özelliği ağır basan yönetimlerin işbaşında olduğu ve istikrarsızlığın kural halini aldığı bir coğrafya olarak dekolonizasyon aşamasına evrilmiştir. Özellikle doğal kaynak zengini ülkelerin yönetimleri, enerji kaynaklarından elde ettikleri önemli miktarlardaki doğal kaynak gelirlerinin küçük bir kısmını, toplumsal desteğin devamını sağlamak maksadıyla toplumun çeşitli kesimlerine aktarmış, diğer büyük kısmını ise kendi politik mevkilerini devam ettirmek amacına özgülemişlerdir (Richards ve Waterbury, 1998: 173-204; Sinkaya, 2015: 7-8). 
Rantiyeci devlet olarak adlandırılan bölge ülkeleri, her ne kadar ciddi miktarda ekonomik kaynağa sahip olsalar da, bu kaynağı etkin şekilde dağıtarak topyekûn bir kalkınma hamlesine tahvil edememiş; bu nedenle de küresel ekonomik sistem içerisinde rekabet gücü yüksek birer aktör konumuna erişememişlerdir (Ünay, 2013: 317-327).

Küresel ekonomik ilişkilerin yoğunlaştığı son yarım yüzyılda, sürdürülebilir bir siyasal, sosyal ve ekonomik altyapısı bulunmayan rantiyer devletler, enerji fiyatlarındaki aşağı yönlü dalgalanmaların ortaya çıkardığı negatif etkileri, transfer harcamalarını kısmak ya da bölgesel yardımları kesmek şeklindeki politikalar vasıtasıyla bölge insanlarına yansıtmışlardır. Bu ise rant kaynaklı ekonomik avantajlardan yararlanmak pahasına politik haklarını feda eden Ortadoğu halklarının, söz konusu ekonomik avantajlarını kaybetmeleriyle bağlantılı olarak siyasal alana dair taleplerini daha sert şekilde dillendirmelerine vesile olmuş; birikimli olarak devam eden bu süreç, birçok farklı unsurun yanında, 2008 yılında başlayan küresel ekonomik/mali krizin de tetiklemesiyle Arap İsyanları sürecinin başlamasına ön ayak olmuştur.

\section{Arap İsyanları Sürecini Kurumsal Yapı Üzerinden Okumak}

Ortadoğu'da kayıp yüzyılın son halkası olarak gelişen Arap isyanları sürecinin nedenlerine ve sonuçlarına ilişkin siyaset bilimi, uluslararası ilişkiler, sosyoloji, iktisat gibi birçok farklı disiplinler ekseninde muhtelif analizler yapılmakta, neden-sonuç ilişkileri kurulmaktadır. Bu izahatların her biri kendi alanında kıymetli görüşleri ihtiva etmekte ise de; küresel, bölgesel ve yerel aktörler üzerinde doğurduğu sosyal, politik ve ekonomik etkileri itibarıyla oldukça önemli bir değişim ve dönüşüm potansiyelini barındıran Arap İsyanları sürecinin nedenleri ve etkilerini nicel veriler etrafında, inter-disipliner bir bakış açısı ile okumaya tabi tutmak meselenin daha kapsamlı ve sarih bir şekilde ortaya konulmasına yardımcı olacaktır.

Bu bağlamda, sabit ve değişken özellikleri itibarıyla benzerlik taşıyan toplumsal organizasyonların neden birbirlerinden farklı değişim ve etkileşim süreçlerine tabi olduğunu kurum kavramı çerçevesinde açıklayan ve yirminci yüzyılın başında Veblen, Ayres, Commons ve Mitchell öncülüğünde, anaakım iktisada kökten bir reddiye olarak ortaya çıkmış olan Kurumsal iktisat Okulu bize bu imkânı sağlamaktadır. Kurumsal iktisat Okulu'nun kurucu teorisinin devamı Eski Kurumsal iktisat olarak adlandırılmakta ve günümüzde Hodgson, Samuels, Dugger ve Rutherford gibi araştırmacıların çalışmaları etrafında, Neo-Kurumsal iktisat olarak varlığını sürdürmektedir.

Diğer taraftan, Yeni Kurumsal iktisat Okulu ise kökenleri itibarıyla kurumsal iktisat okuluna bağlı olmakla beraber Coase, North, Ostrom ve Williamson'un önderliğinde, anaakım iktisadı tamamen reddetmeyip rasyonalite ve tam bilgi gibi gerçekçi olmayan varsayımlar yerine işlem maliyetleri, mülkiyet hakları, eksik sözleşmeler, hukukun üstünlüğü gibi kurumsal açıklayıcıları ve yönetişim göstergelerini ikame etmektedir. Buna göre anaakım iktisatta görülen piyasa ve firma gibi unsurların işleyiş̧inin de kurumsal süreç içerisinde değerlendirilmesinin önemi vurgulanmak suretiyle yerleşik iktisadın reformist bir tamamlayıcısı olarak farklı bir metodolojik çerçeve sunmaktadır (Çetin; 2012: 65-66).

Yeni kurumsal iktisat okulu bağlamında kurum kavramı ile "toplumsal aktörler arasındaki ilişki formlarını belirleyen ve yine insanlarca oluşturulmuş kısıtlamalar" yani kısaca "bir toplumda oynanan oyunun kuralları" ifade edilmektedir (North, 2002: 9). Yine bağlantılı olarak, kurumların altyapısını oluşturan alt prensipler kural, kurumsal değişimini sağlayan araçlar ise organizasyon olarak adlandırılmaktadır. 
Kurumlar, temel olarak kapsayıcı kurumlar ve dışlayıcı kurumlar olmak üzere iki kısımda değerlendirilmektedir (Acemoğlu ve Robinson, 2013: 74-77). Özetle, toplumsal yaşamın her alanındaki gri alanları yani belirsiz noktaları azaltarak, aktörler arası ilişkileri daha net kurallara indirgeyen kurumlara kapsayıcı, aksi kurumlara ise dışlayıcı kurumsal yapı adı verilmekte; kurumsal yapının kapsayıcılık ya da dışlayıcılık seviyesi, kurumsal kalite olarak ölçülmektedir.

Çeşitli metotlar kullanarak kurumsal yapının kapsayıcılık seviyesini (kurumsal kalite) nicel verilere dönüştüren birçok endeks bulunmaktadır. Bu endekslerden bir kısmı oldukça geniş kurum setini ihtiva ederken, diğer bazıları da spesifik olarak tek bir kuruma yoğunlaşmaktadır. Bu endeksler genel olarak, yapılan araştırmanın ilgili yılın ekonomik performansından etkilenmesini ifade eden öznellik, gelişmiş ülkelerin kurumsal kalitenin arttırılmasına ayıracakları kaynağın fazlalığının getirdiği sapmayı dikkate alan içsellik ve araştırmaya konu kişilerin kendi planlarını/programlarını öncelemeleri sonucu ortaya çıkan yanlıık gibi bir takım problemleri barındırmakta ise de bu sorunlar çeşitli istatistikî metotlarla aşılmaktadır (Uğur, 2011: 39-40).

Bu çalışmada, güvenilirlik düzeyi yüksek olması, muhtelif kaynaklardan derlenen kapsamlı verileri ihtiva eden ideal bir kurum setini içermesi, daha geniş bir zaman dilimini kapsaması gibi özelliklerinden dolayı Dünya Bankası tarafından yıllık olarak yayımlanan ve siyasal, ekonomik ve sosyal kurumlar olmak üzere üç alt başlık altında altı parametreden oluşan Dünya Yönetişim Göstergelerini kullanacağız. Bu doğrultuda, söz konusu kurumların muhteviyatına kısaca değinilecektir.

Siyasal kurumlar, ifade özgürlüğü ve hesap verebilirlik ile siyasal istikrar ve şiddetsizlik başlıklarından oluşmakta olup, seçme ve izleme göstergeleri olarak kavramsallaştırılmaktadırlar. ifade özgürlüğü ve hesap verebilirlik göstergesi; birbiriyle ilişkili olan kendini açıklama hürriyeti, özgür basın algısı, örgütlenme hakkı, seçme ve seçilme hakkı/siyasal katılımcılık, adil seçim sistemi, siyasi sorumluluk ve hesap verebilirlik, değişkenlerini içermektedir. Siyasal istikrar ve şiddetsizlik göstergesi ise yönetimin politik güdülü şiddet ya da terör gibi hukuki olmayan ve cebir içeren yollarla devrilmesi veya zedelenmesi temayülünü kapsamaktadır (Kaufmann, Kraay ve Mastruzzi, 2010: 4).

Ekonomik kurumlar, yönetimin etkinliği ile düzenlemelerin kalitesi parametrelerini içermekte ve verimlilik göstergeleri olarak da adlandırılmaktadırlar. Yönetimin etkinliği; kamu hizmetlerinin kalitesi ve politik tercihlerden bağımsızlığı, yönetimin politika yapımı ve icrası sürecinin yalınlığı ve sürati ile bu politikalara bağlılığının sağladığı itibar algısı ifade etmektedir. Düzenlemelerin kalitesi ise yönetimin piyasalara yönelik güven odaklı politikalar oluşturma ve özel sektörü kalkındırmaya matuf düzenlemeleri hayata geçirebilme yeteneğini ölçmektedir (Kaufmann, Kraay ve Mastruzzi, 2010: 4).

Sosyal kurumlar, yolsuzluğun kontrolü ile hukukun üstünlüğü göstergelerinden meydana gelmekte olup, saygı/itibar göstergeleri şeklinde ifade edilmektedir. Yolsuzluğun kontrolü, kamu kudretinin özel çıkarlar lehine kötüye kullanılmasının önlenmesi olarak tanımlanmaktadır. Hukukun üstünlüğü ise toplumun hukuki düzenlemeleri benimseme ve kurallara uyma eğilimi, mülkiyet hakkının güvence altında olması, sözleşmelerin uygulanabilirliğini sağlayacak yaptırım mekanizmalarının etkin çalışması, adli sistemin bağımsızlığı ve tarafsızlığı gibi değişkenleri kapsamaktadır(Kaufmann, Kraay ve Mastruzzi, 2010: 4). 


\section{Küresel Sistem İçerisinde Ortadoğu'nun Kurumsal Yapısı}

Arap isyanları sürecinin ilgili ülkeler açısından beklenen bir durum olup olmadığına bakmadan önce, Ortadoğu'nun genel kurumsal yapısının dünyadaki diğer bölgelere kıyasla nasıl bir görünüm arz ettiğinin siyasal, ekonomik ve sosyal kurumlar ekseninde incelenmesi önem taşımaktadır. Bu bağlamda yapılacak olan mukayeseli ve dinamik analiz esnasında Dünya Bankası'nın Dünya Yönetişim Göstergeleri esas alınacak olup; mezkûr kurumların gelişim trendinin açıklanması esnasında Ekonomist Dergisi'nin (The Economist) Demokrasi Endeksi, Mülkiyet Hakları Birliği'nin (Property Rights Alliance) Uluslararası Mülkiyet Hakları Endeksi, Fraser Enstitüsü’nün Dünya Ekonomik Özgürlük Endeksi, Uluslararası Şeffaflık Örgütü’nün (Transperancy International) Yolsuzluk Algılama Endeksi, Özgürlük Evi'nin (Freedom House) Dünya'da Özgürlükler Endeksi, Dünya Ekonomik Forumu'nun Küresel Rekabet Gücü Endeksi, Heritage Vakfı'nın Ekonomik Özgürlükler Endeksi ve Dünya Bankası ile Uluslararası Finans Kurumu'nca hazırlanan İş Yapma Endeksi (Doing Business) raporlarında yer alan açıklamalardan da yararlanılacaktır.

Ortadoğu'nun, ifade özgürlüğü ve hesap verebilirlik açısından dünya genelinde en düşük skorlara sahip bölge olduğu, Şekil 1'den görülebilmektedir. Zira Ortadoğu, Ekonomist'in yıllık olarak yayımladığı Demokrasi Endeksi'nin 2015 yılı sıralamasına göre içerisinde "tam demokrasi" olarak tasnif edilen herhangi bir ülke barındırmayan tek bölge olduğu gibi, "otoriter rejim" olarak adlandırılan yönetim biçimlerinin de en yoğun olarak bulunduğu bölgedir.

Şekil 1: Dünya'da "ifade Özgürlüğü ve Hesap Verebilirlik" (1996-2015)

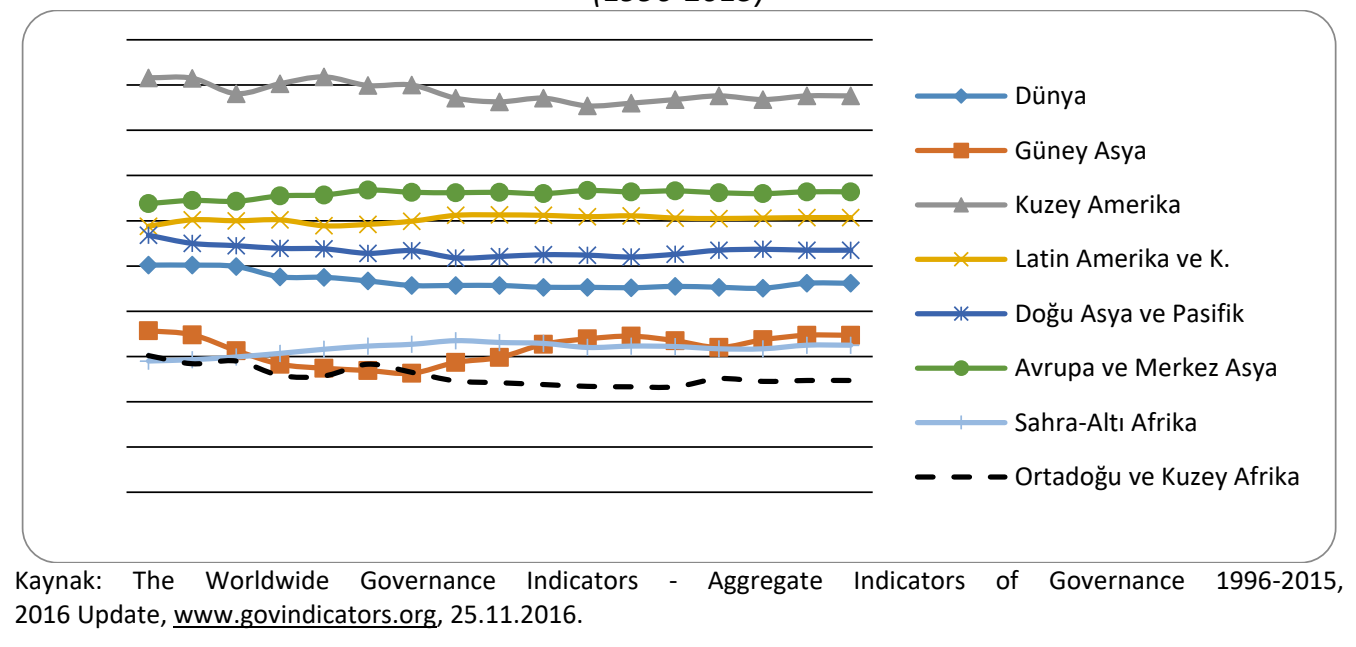

Diğer taraftan, Özgürlük Evi (Freedom House) nin 2016 Yılı Dünya Özgürlükler Endeksi verilerine göre Ortadoğu'da yer alan 18 ülkeden 13'ünün "özgür değil", 3'ü ise "kısmi özgür" olarak tasnif edilmektedir. Aynı kuruluş tarafından yayımlanan 2015 Yılı Basın Özgürlüğü Endeksi verilerine göre de, Ortadoğu'da yer alan 19 ülkeden 15'i “özgür değil”, 3'ü "kısmi özgür" ve 1'i ise "özgür" olarak sınıflandırılmaktadır ki bu ülke, genel yapısı ve özellikleri itibariyle bölge ülkelerinden önemli ölçüde ayrışan İsrail'dir. 
Şekil 2: Dünya'da "Siyasal istikrar ve Şiddetsizlik" (1996-2015)

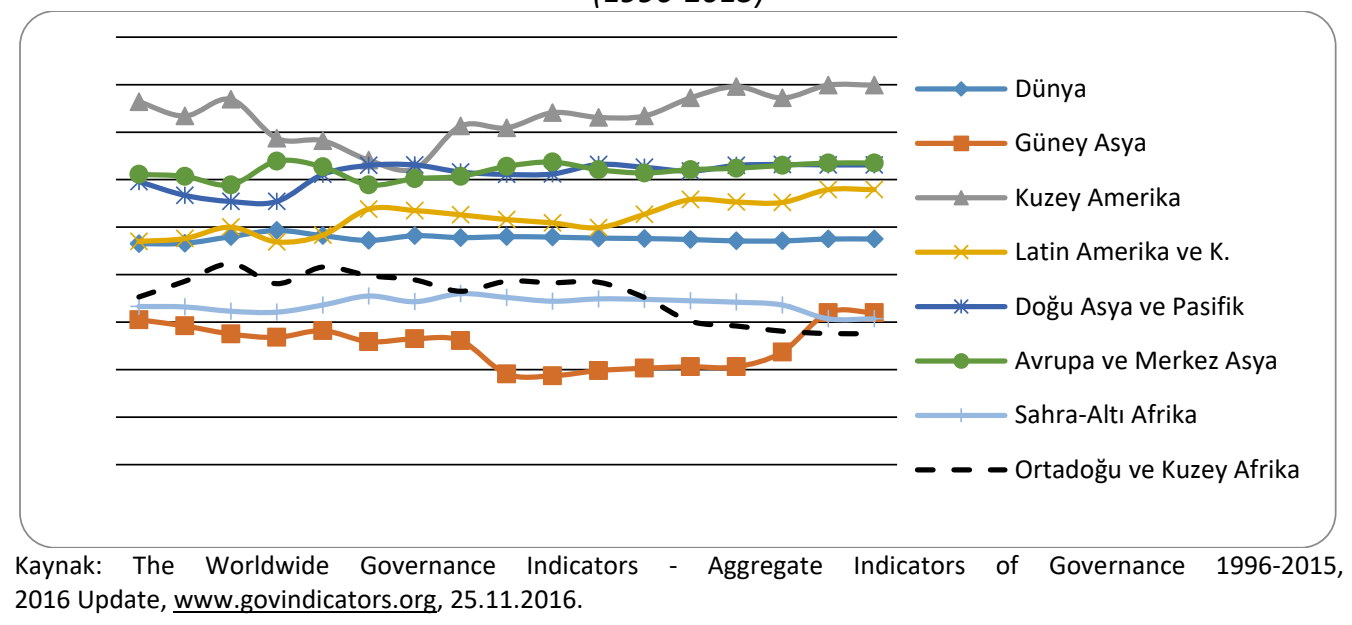

Ortadoğu'nun, siyasal istikrar ve şiddetsizlik açısından dünya genelinde Sahra-Altı Afrika ve Güney Asya ile birlikte en düşük skorlara sahip bölge olduğu Şekil 2'den izlenebilmektedir. Siyasal istikrar ve şiddetsizlik göstergesinin, yönetimin katılımcı niteliğinden ziyade, istikrarlı ve sürdürülebilir olma yeteneğini ifade ettiği göz önüne alındığında (Bkz. Brunetti, 1997), bölgenin dış müdahaleye açık yapısı ve savunma bürokrasisinin yönetim/hükümet üzerindeki yönlendirici etkinliği, Ortadoğu'nun neden az gelişmiş bölgelerle eşdeğer skorlara sahip olduğunu açıklamaktadır (Bkz. Stansfield, 2011).

\section{Şekil 3: Dünya'da "Yönetimin Etkinliği"}

(1996-2015)

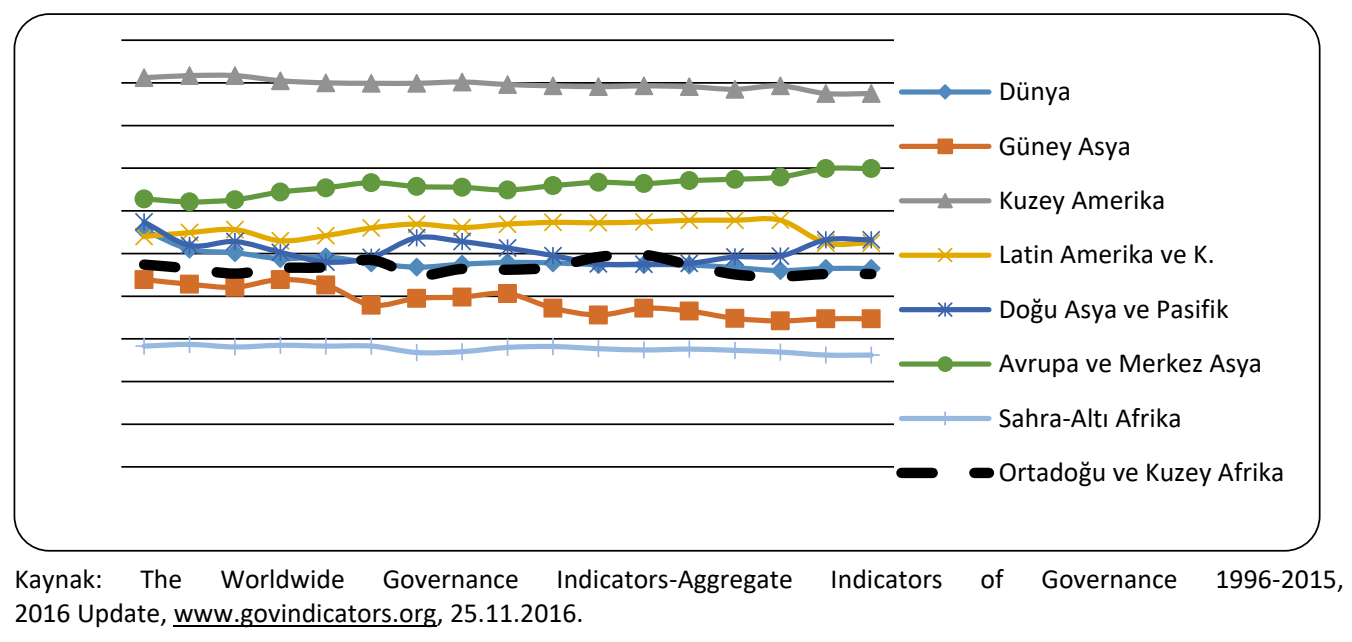


Keza, Arap isyanları süreci sonrasında oluşan şiddet sarmalının yayılma etkisiyle tüm bölgeyi istikrarsızlaşması sonrasında, Ortadoğu'nun ahvali daha da kötü bir hale bürünmüş ve 2014 yılı itibarıyla da dünyanın en kötü bölgesi görünümünü almıştır.

Ortadoğu ülkelerinde; ekonomi içerisinde kamu ekonomisinin hacmi, bu pay içerisinde askeri harcamaların oldukça büyük bir yer tutuyor olması, toplam kamu personeli içerisinde askeri personelin nispetinin yüksekliği, siyasetin finansmanının doğrudan ya da dolaylı olarak rant gelirlerine bağımlılığı, siyasi ve ekonomik gücün elit bir zümre içinde tekelleşmesi ve patronaj ilişkilerinin dışlayıcı etkisi, idari ve siyasal hesap verme sorumluluğunu gözetecek etkin denge ve denetim mekanizmaları bulunmaması nedeniyle yönetimlerin politika vaatlerini yerine getirmedeki düşük güven algısı gibi negatif unsurlar nedeniyle bölgede yönetimin etkinliği skorunun neden dünya ortalamasının altında olumsuz bir görünüme sahip olduğu, Şekil 3'ten de izlenebilmektedir (Bkz. Kadri, 2014; Stansfield, 2011).

Bu bağlamda, Arap İsyanları öncesinde yönetimlerin vaat ve politika öngörülerine/metinlerine olan nispi bağlılıklarının, süreç sonrasında oluşan karmaşa döneminde iyice gevşediği ve bu nedenle yönetimin etkinliği göstergesi bakımından trendin daha da kötü bir seyir izlemeye başladığı görülmektedir.

Şekil 4: Dünya'da "Düzenlemelerin Kalitesi"

(1996-2015)

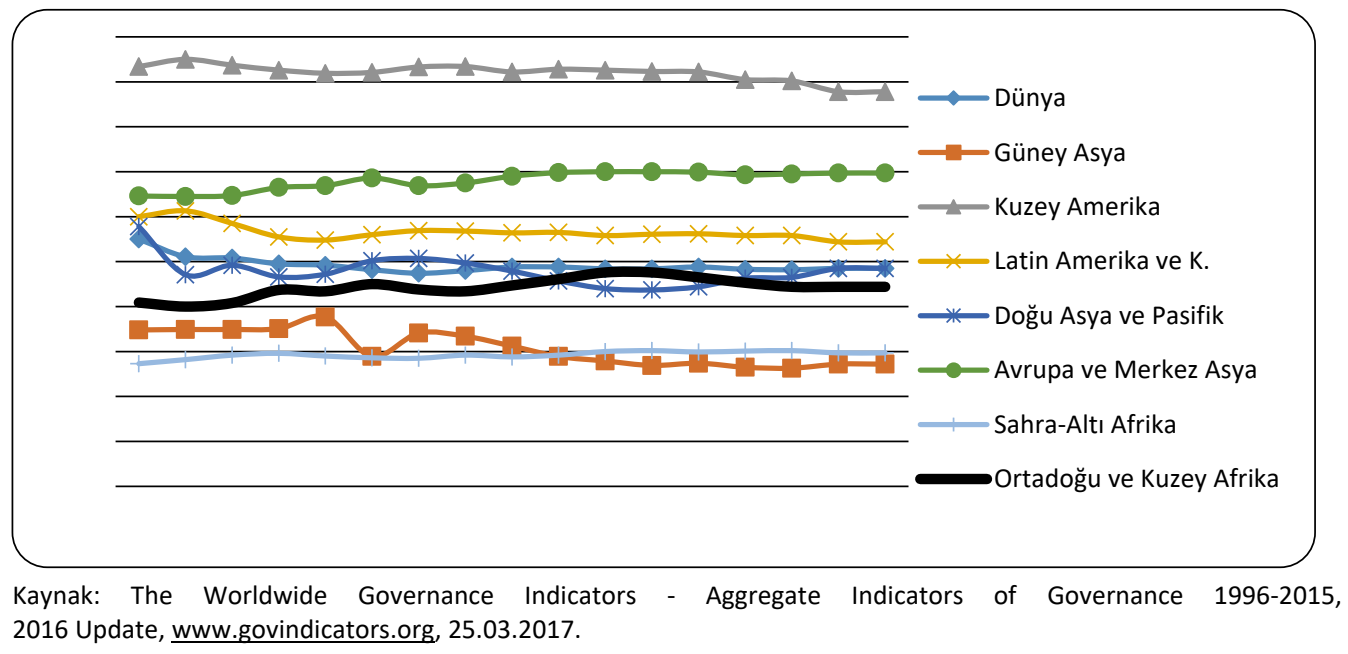

Şekil 4 incelendiğinde Ortadoğu'nun, piyasalara yönelik oldukça kapsamlı ve çeşitli parametreleri ihtiva eden düzenlemelerin kalitesi göstergesi açısından dünya ortalaması düzeyinde bir skora sahip olduğu görülmektedir. Biraz evvelde belirtildiği üzere siyasal kurumlar açısından kötü bir görünüm arz eden Ortadoğu'da işbu skorun nispeten yüksek olması şaşırtıcı karşılanabilmektedir. Bu durum, bölgenin dünya doğal kaynak rezervlerinin yaklaşık 2/3'üne sahip olması ile doğrudan bağlantılıdır (Bkz. BP Statistical Review, 2016 Update, 2017). Her ne kadar doğal kaynak rezervleri bölge geneline homojen olarak dağılmamış ise de, dünya petrol üretiminin neredeyse yarısını gerçekleştiren Körfez İ̧̧birliği Konseyi (KiK) üyesi ülkelerin neo-liberal politi- 
kalara öncelik vererek mal ve hizmet piyasası, bankacılık ve finans sistemi ile iş ve ticaret hayatına ilişkin kapsayıcı düzenlemelere gitmeleri, Ortadoğu'nun nispeten yüksek skorlar elde etmesinde belirleyici rol oynamaktadır.

Genel olarak kamu sektörünün şeffaflık düzeyindeki sınırlılık/kapalılık, bağımsız denetim/değerlendirme mekanizmalarının bulunmaması ve kayırmacılık/yeğencilik (nepotizm) uygulamalarının yaygınlığı nedenleriyle, Ortadoğu'da yolsuzluğun kontrolü skorunun dünya ortalamasının altında seyrettiği Şekil 5'ten izlenebilmektedir. Uluslararası Şeffaflık Örgütü tarafından yayımlanan 2016 Yılı Yolsuzluk Algılama Endeksi'nin sonuçları da, bölge ülkelerinin neredeyse tamamının yolsuzluğun kontrolü açısından kritik eşik olan 50 puanın altında kaldığını doğrulamaktadır.

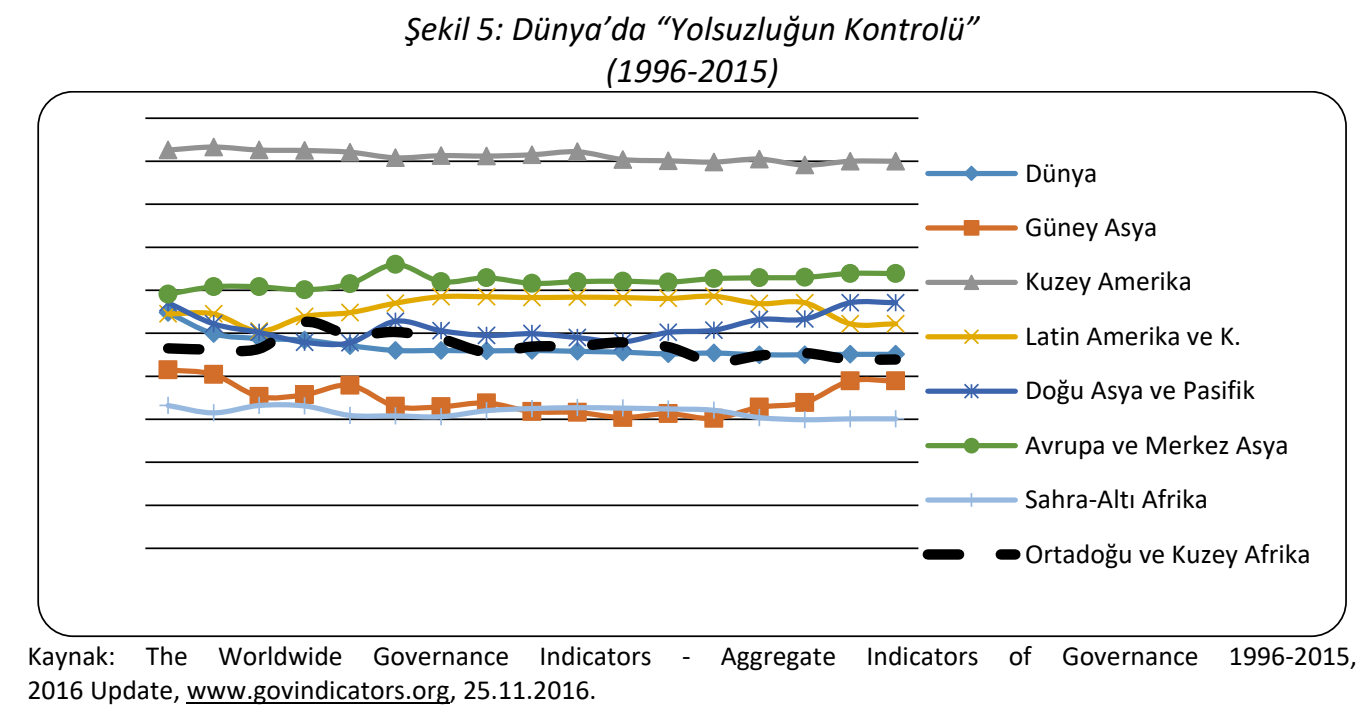

Genel olarak otoriter-baskıcı yönetim biçimleriyle yönetilen Ortadoğu ülkelerinde yargı kurumlarının bağımsız ve tarafsız olarak işlediğine dair algının zayıf olması, maddi ve entelektüel mülkiyet hakları güvencesini sağlamaya matuf yasal çerçevenin kapsayıcılık düzeyinin düşük seviyelerde bulunması, sözleşmelerin uygulanabilirliği ve uyuşmazlıkların giderilmesine yönelik mekanizmaların etkin olmaması gibi nedenlere binaen, hukukun üstünlüğü göstergesinin bir hayli kötü seviyelerde bulunduğu düşünülmektedir. Oysaki özellikle turizm ve finansal hizmetler sektörünün gelişmesini müteakip Körfez İşbirliği Konseyi (KiK) üyesi ülkelerde gerek maddi gerekse entelektüel mülkiyet hakları ve sözleşmeler hukuku çerçevesinin gelişmesiyle birlikte elde edilen yüksek skorlar, bölge ortalamasının da dünya ortalamasına eşdeğer bir seviyeye yükselmesini sağlamıştır.

Öte yandan, Arap isyanları sürecinde, yönetimler tarafından isyanların bastırılması maksadıyla uygulanan sert askeri ve kolluk uygulamaları nedeniyle, zaten dengeli bir görünüm arz etmeyen özgürlük-güvenlik ilişkisinin özgürlüklerin aleyhine olacak şekilde daha da bozulduğu ve böylece ilgili göstergenin trendinin aşağı yönlü bir vaziyet aldığı Şekil 6'dan izlenebilmektedir. 
Şekil 6: Dünya'da "Hukukun Üstünlüğü"

(1996-2015)

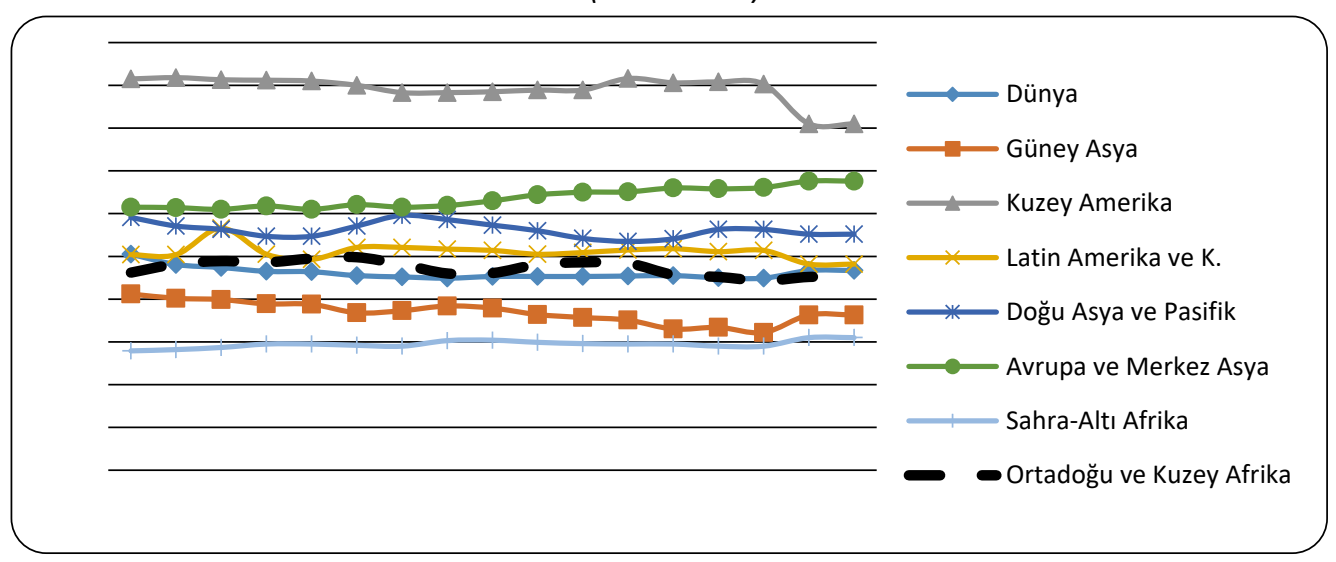

Kaynak: The Worldwide Governance Indicators - Aggregate Indicators of Governance 1996-2015, 2016 Update, www.govindicators.org, 25.11.2016.

Bölgeler arasında yapılan bütün bu kıyasların özeti olarak; literatürde Arap İsyanları sürecinin nedenlerine ilişkin öne sürülen; ifade ve basın özgürlüğü ile bağlantılı diğer temel hak ve özgürlüklerin alanının daraltıldığı, siyasal katılımcılı̆̆ın oldukça kısıtlı olduğu, politik ortamın öngörülebilir olmadığı, şeffaf ve verimli işleyen bir bürokratik yapının bulunmadığı, etkin bir adli mekanizmanın tesis edilmediği, özellikle siyasi yolsuzlukların kontrol altına alınamadığı hatta yer yer adeta bir "yönetim modeli" halini aldığı, mülkiyet altyapısının tam olarak yerleşmediği ve gerek fiziki gerekse fikri mülkiyet hakları güvencesinin sağlanamadığı şeklindeki tezleri destekleyen verilerin, Ortadoğu için kurumsal kalite düzeyinin düşüklüğü bağlamında da teyit edildiği fakat süreç ertesinde, kısa vadede müspet ya da menfi yönde belirgin bir kırılma yaşanmadığı gözlemlenmektedir.

\section{Arap İsyanları Kurumsal Değişimi Tetikler mi/Tetikledi mi?}

Küresel sistem içerisinde Ortadoğu'nun bölgeler arası mukayeseli görünümüne değindikten sonra, Arap isyanlarına giden süreçte muhatap bölge ülkelerinin kurumsal kalite düzeylerinin seyri ve kurumsal yapılarındaki kırılmaların mahiyetine bakılması daha açıklayıcı olacaktır.

Arap isyanları sürecinde büyük çaplı olayların yaşandığı Tunus, Mısır, Libya, Yemen, Bahreyn, Suriye'nin, ifade özgürlüğü ve hesap verebilirlik göstergesi bağlamında, hâlihazırda dünya bölgeleri arasında en kötü ortalama skora sahip olan Ortadoğu ortalamasının dahi altında puana sahip oldukları Şekil 7'den izlenebilmektedir.

Bununla birlikte, bu ülkelerde katılımc bir siyasal yaşamın oluşturulmasına yönelik kısmi bazı kazanımlar elde edilmiş ve böylece ilgili göstergede kısa süreli de olsa bir iyileşme trendi sağlanmış, ancak daha sonra mezhep kökenli çatışma, askeri müdahale, iç savaş ve/veya vekâlet savaşları gibi büyük çaplı olaylar nedeniyle söz konusu demokratik kazanımlardan kaybedilerek siyasal kurumsal yapılar daha da parçalamıştır. 
Şekil 7: Arap isyanları Ülkelerinde "ifade Özgürlügü ve Hesap Verebilirlik" (1996-2015)

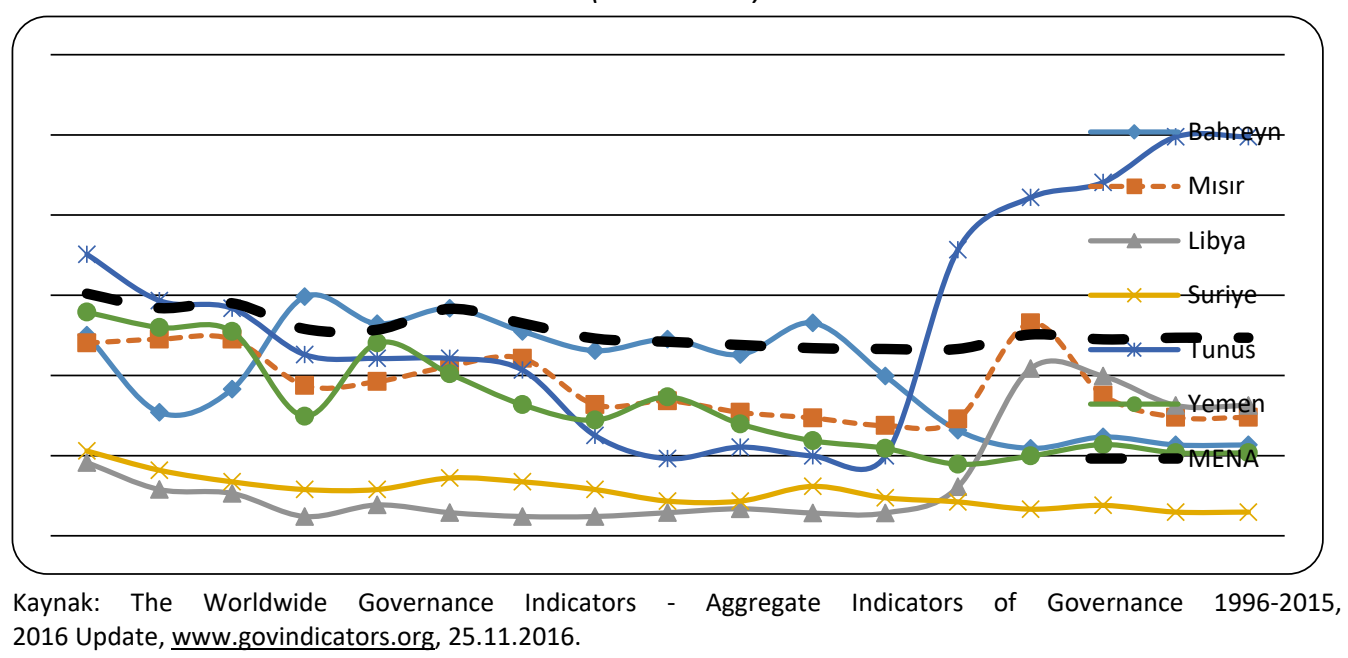

Arap isyanlarının başladığı Tunus, bu gelişmelerin tek istisnasını oluşturmaktadır. Şöyle ki Tunus'ta mevcut yönetimin devrilmesinin hemen ertesinde halk, eski rejimin devamı olduğu yönünde tereddütlere neden olan bazı simge isimlerin yönetimden dışlanması hususunda ısrarcı olmuştur. Ayrıca temel hak ve özgürlüklere daha çok referans veren yeni bir anayasa oluşturulması ve hem başkanlık hem de meclis seçimlerin sorunsuz olarak gerçekleştirilmesi sürecine kadar meydanlarda kendisini hissettirerek, taleplerinin takipçisi olduğu algısını güçlendirmiştir (Ayhan, 2012: 56-72; Okumuş, 2015: 44-50).

Böylece halk isyanları sonunda Tunus'taki otoriter yapı kııılmış ve elde edilen kazanımların kurumsallaşmasında/yerleşik hale gelmesinde nispi bir başarı yakalamıştır. Tunus'un bu durumu, Ekonomist Dergisi'nin 2014 yılı Demokrasi Endeksi'nde tam demokrasi kategorisinden hemen sonraki "kısmi demokrasi" kategorisinde sınıflandırılması ve yine Freedom House'un 2015 yılı Dünya Özgürlükler Endeksi'nin politik özgürlükler kategorisinde de "özgür ülke" statüsüne yükselmesi ile teyit edilmiştir.

Arap isyanları öncesinde siyasal istikrar ve şiddetsizlik göstergesi açısından özellikle Yemen'in oldukça kötü, Bahreyn, Mısır ve Suriye'nin bölge ortalaması civarında ve Tunus ile Libya'nın ise bölge ortalamasının üzerinde skorlara sahip oldukları, Şekil 8'den anlaşılmaktadır. Öte yandan, hangi düzeyde skora sahip olursa olsun, bütün bu ülkelere dair siyasal istikrar algısındaki azalmanın, Arap isyanları öncesinde belirginleşmeye başladığı hususu da aynı şekilden açıkça izlenebilmektedir.

Her ülkenin kendi iç dinamiklerinin bulunduğu göz önüne alındığında bu duruma tek elden bir açıklama getirmek mümkün görünmemektedir. 2008 yılında başlayan küresel ekonomik kriz bir taraftan bölge ekonomilerinin temelini oluşturan enerji fiyatlarında düşüşe neden olmuş, diğer taraftan ise gelişmiş ülkelerin ithalat miktarlarını kısmalarına sebebiyet vermiştir. Bu bağlamda ortaya çıkan daraltıcı etkilerle birlikte, gelirlerinin önemli bir bölümünü doğrudan ya da dolaylı olarak doğal kaynak ihracı ve bağlantılı iktisadi aktiviteler kanalıyla yurtdışından temin eden ve rantiyer özelliği gereği toplumsal muhalefeti sosyo-ekonomik tedbirlerle kontrol altına 
alan yönetimlerin elleri zayıflamıştır. Bunun sonucunda ortaya çıkan toplumsal memnuniyetsizlik, küresel ekonomik krizin de tetikleyici etkisiyle, zaten hassas dengeler üzerinde duran toplumsal muhalefeti hareketlendirerek Arap isyanları sürecinin adeta öncüllerini oluşturmuştur (Hanieh, 2015: 263-270).

Şekil 8: Arap Isyanları Ülkelerinde "Siyasal Istikrar ve Şiddetsizlik" (1996-2015)

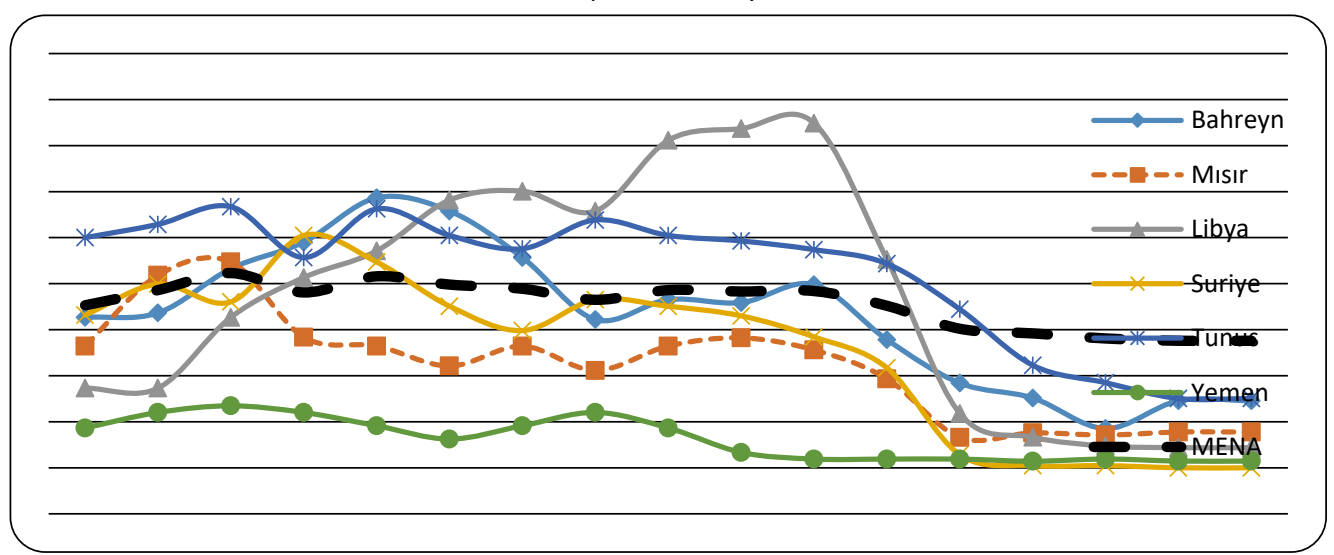

Kaynak: The Worldwide Governance Indicators - Aggregate Indicators of Governance 1996-2015, 2016 Update, www.govindicators.org, 25.11.2016.

Ve fakat bu somut toplumsal gerçeğe dayanan Arap isyanları sürecinin sonuçlarının, silahlı kuvvetlerin büyüklüğü ve yönetim-savunma bürokrasisi ilişkilerinin yapısal özelliklerinden doğrudan etkilendiği anlaşılmaktadır. Bahreyn ve Mısır'da bizzat otoriter yönetimler tarafından arzulandığı şekliyle oluşturulan ve bunun bir uzantısı olarak isyanlar sürecinde siyasi iktidardan yana tavır alan silahlı kuvvetler, isyan dalgalarının bastırılması ya da karşı devrim suretiyle yönetim yapılarında büyük değişikliklerin ortaya çıkmasının önünde en büyük engeli oluşturmuşlardır. Tunus, Libya ve Yemen gibi kurumsal altyapısı kuvvetli olmayan savunma bürokrasisi yapılanmalarının bulunduğu ülkelerde ise sonuçları değişmekle birlikte yönetimler daha çabuk devrilmiş ve isyanlar daha hızlı bir şekilde yayılmıştır (Vincent, 2014: 217-222; Bilgin, 2014: 224228).

Şekil 9 incelendiğinde, parçalı/dağınık sosyal yapıları içerisinde barındıran ve merkezi devlet organizasyonlarının kurumsallaşma seviyesi zayıf olan Libya, Yemen ve Suriye'de tam kamusal hizmetlerin dahi yeterli ölçüde ve etkin üretilememesi ve sunulamaması nedeniyle yönetimin etkinliği skorlarının düşük seviyelerde kalmıştır. Tarihi arka planı sebebiyle söz konusu ülkelere nispeten köklü bir devlet geleneğine sahip olan Mısır'da ise isyan öncesinde mevcut otoriter yönetimin öngörülebilir politika metinleri üretememesi ve/veya oluşturulan politika metinlerine bağı kalmaması, bu nedenle de bürokratik kalitenin geliştirilmesi ve kamu hizmetinin daha etkin sunulması için sürdürülebilir bir ajanda belirlenememesi gibi sorunlara binaen, yönetimin etkinliği skorunun bölge ortalaması civarında ancak istikrarsız bir seyir takip ettiği görülmektedir. 
Şekil 9: Arap İsyanları Ülkelerinde "Yönetimin Etkinliği"

(1996-2015)

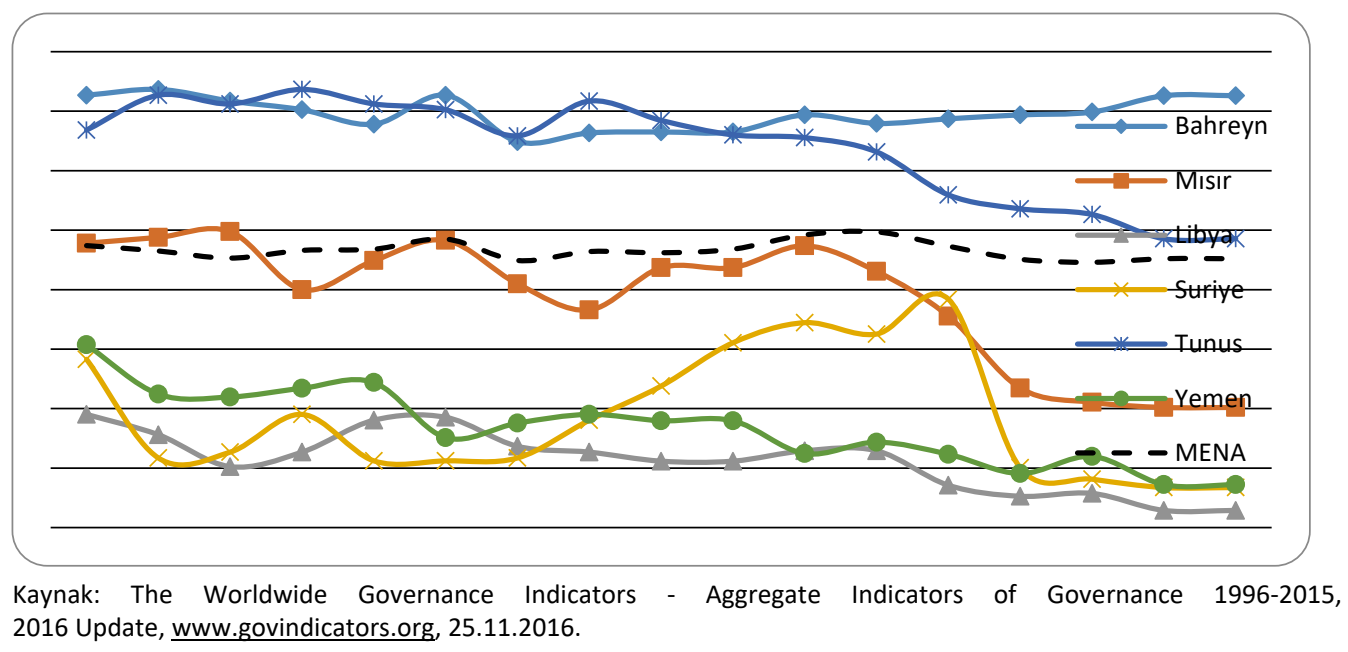

Öte yandan, sahip bulunduğu doğal kaynaklardan elde ettiği gelirler sayesinde ekonomik altyapısı kuvvetli olan Bahreyn'de, rantiyeci devlet olgusunun avantajları kullanılarak vergilerin azaltılması ve sosyal yardımların arttırılması şeklindeki politika uygulamaları sayesinde isyanların neredeyse hiçbir negatif etkisi hissedilmemiştir. Neo-liberal politikaları neredeyse eksiksiz şekilde uygulayarak ekonomik aktivite içerisinde devletin payını azaltan ve özellikle Avrupa ülkeleriyle gerçekleştirdiği dış ekonomik ilişkileri sayesinde bürokratik altyapısı nispeten gelişmiş bulunan Tunus'ta ise yönetimin etkinliği skoru bölge ortalamasının oldukça üzerinde seyretmektedir. (Hanieh, 2014: 112-116; Öztürkler, 2012: 53-58).

\section{Şekil 10: Arap Isyanları Ülkelerinde "Düzenlemelerin Kalitesi"}

(1996-2015)

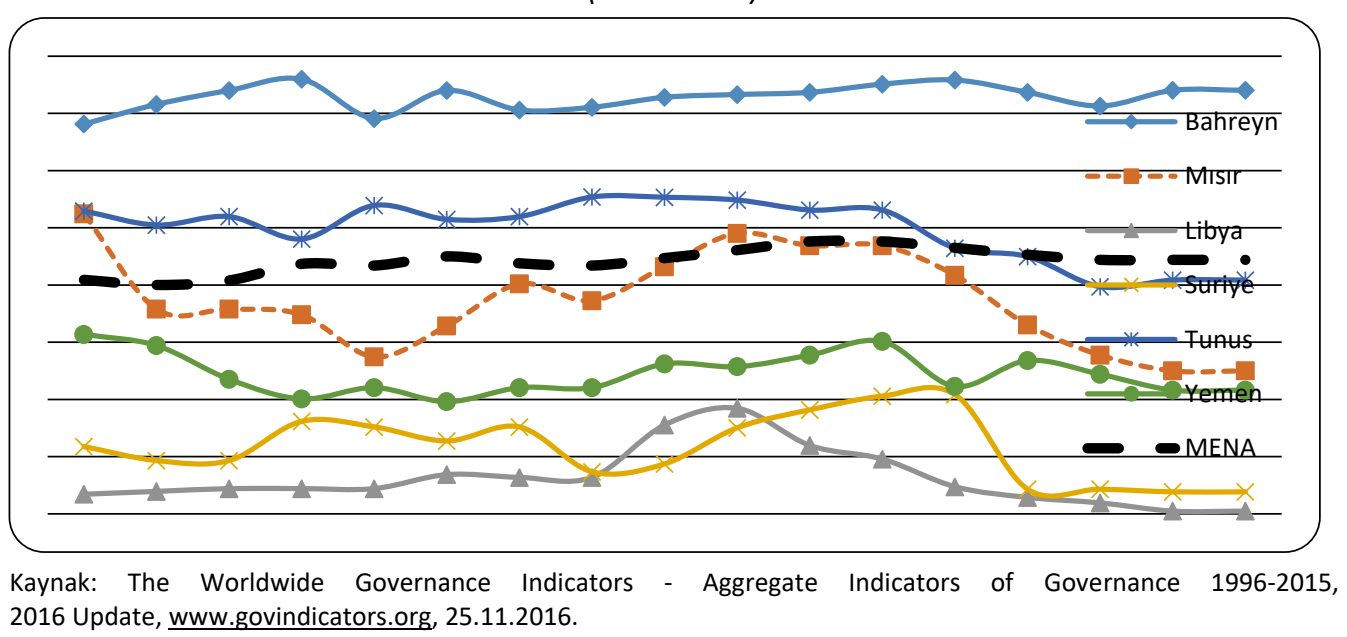


Kamu iktisadi teşekküllerinin baskınlığı ve doğrudan yabancı sermaye yatırımları üzerindeki sektörel kısıtlara rağmen modern iletişim ve ulaşım altyapısının sağladığı ticari rekabet gücü ve bölgenin finans ve bankacılık merkezi olup önde gelen çokuluslu şirkete ev sahipliği yapması sebebiyle Bahreyn'de piyasalara yönelik düzenlemelerin kalitesi göstergesinin yüksek skorlara sahip olduğu ve bu trendin Arap isyanları sürecinden etkilenmediği de Şekil 10' dan anlaşılmaktadır (Pierce, 2008, s.90).

Diğer taraftan, daha önce de kısmen bahsedildiği üzere, uluslararası ekonomik kuruluşlar ile yaptığı anlaşmalar bağlamında küresel ekonomik sistemle entegre bir yapı sergileyerek neoliberal politikaların periferideki başarı örneği olarak gösterilen Tunus'ta, coğrafi yakınlığın vermiş olduğu avantaj sayesinde Avrupa Birliği ülkelerine yönelik mal ve hizmet ihracatı ile ülkenin kurumsal yapısı arasında iki yönlü dinamik bir ilişkinin var olduğu bilinmektedir.

Buna göre 2008 yılında başlayan küresel ekonomik krizin tüm gelişmiş ekonomiler gibi Avrupa Birliği ülkelerini de sarsan daraltıcı etkilerinin dolaylı olarak Tunus'a da yansıması sonrasında, bahse konu etkileşim bağlamında ülkede piyasaların kurumsal altyapısında ortaya çıkan zayıflama emareleri, Arap isyanları ile oldukça hızlı bir kötüleşme evresine girmiştir. Yine, yönetimlerin sağlam politikalar oluşturma ve bunları uygulamak suretiyle özel sektörü kalkındırma maksatlı kapsayıcı düzenlemelere sahip olmayan Mısır, Libya, Suriye ve Yemen'in ise zaten düşük olan skorlarının Arap isyanları süreciyle olumsuza döndüğü görülmektedir.

\section{Şekil 11: Arap İsyanları Ülkelerinde "Yolsuzluğun Kontrolü"}

(1996-2015)

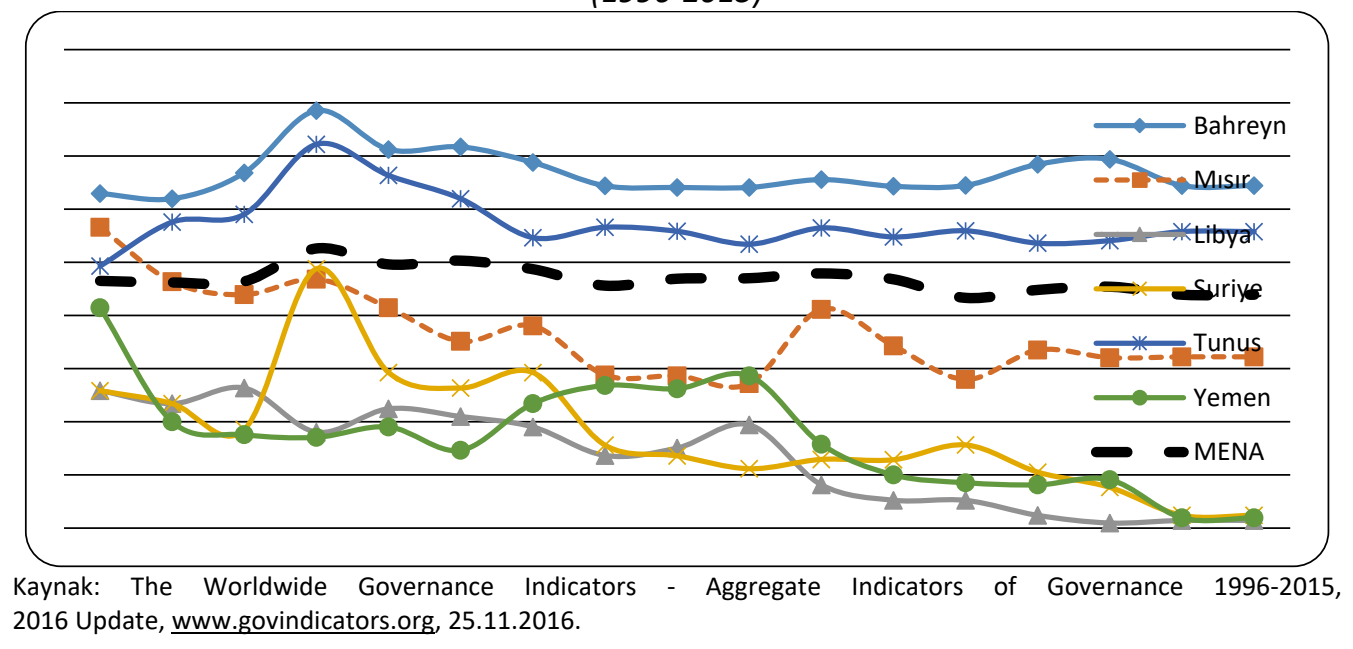

Libya, Mısır, Suriye ve Yemen'de kurumsal altyapının en zayıf halkalarının başında sayılan yolsuzluk olgusunun giderilmesine dair belirgin ve sürdürülebilir bir ajanda mevcut değildir. Bu durumun Arap isyanları süreci sonrası oluşan sosyo-politik karmaşa ortamlarında artan gayrı resmi ilişkiler dolayısıyla daha da kötü bir görünüm sergilediği de Şekil 11'den izlenebilmektedir.

Diğer taraftan bölge ülkelerinin genel karakteristiği ile benzer şekilde bürokrasinin işleyişi sürecinde kamu kudretinin kişisel çıkarlar lehine kullanılması şeklindeki uygulamalara Tunus'ta da rastlanmakta ise de, Arap isyanlarının başlangıç noktası olan bu ülkede yaygın olan yolsuzluk 
söyleminin, esas olarak devrik lider Zeynel Abidin Bin Ali'nin ailevi ve siyasi merkezli çarpık rüşvet ilişkilerini işaret ettiği özellikle sosyal medya kanalıyla ifşa edilmiştir. Buna göre yolsuzluğun kontrolü bağlamında belirli bir gündemi bulunan Tunus'ta ilgili göstergenin skoru bölge ortalamasının üstünde ve istikrarlı olarak seyretmektedir (Gana, 2014: 37-40).

Küresel ekonomik sistemle bütünleşik bir görünüm sergileyen ve rekabet gücü açısından gerek dünyanın gerekse Ortadoğu'nun önde gelen inovasyon-odaklı ülkelerinden olan Bahreyn'de yolsuzluk olgusunun iş ortamını olumsuz etkileyerek ekonomik aktiviteyi daraltıcı yönde etkiler sergilediği yönündeki farkındalık yüksek düzeydedir. Yasal altyapısı da bu doğrultuda şekillenmiş bulunan Bahreyn'de yolsuzluğun kontrolü göstergesine ait skorlar yüksek düzeyde bir seyir izlemektedir.

Şekil 12: Arap Isyanları Ülkelerinde "Hukukun Üstünlüğü"

(1996-2015)

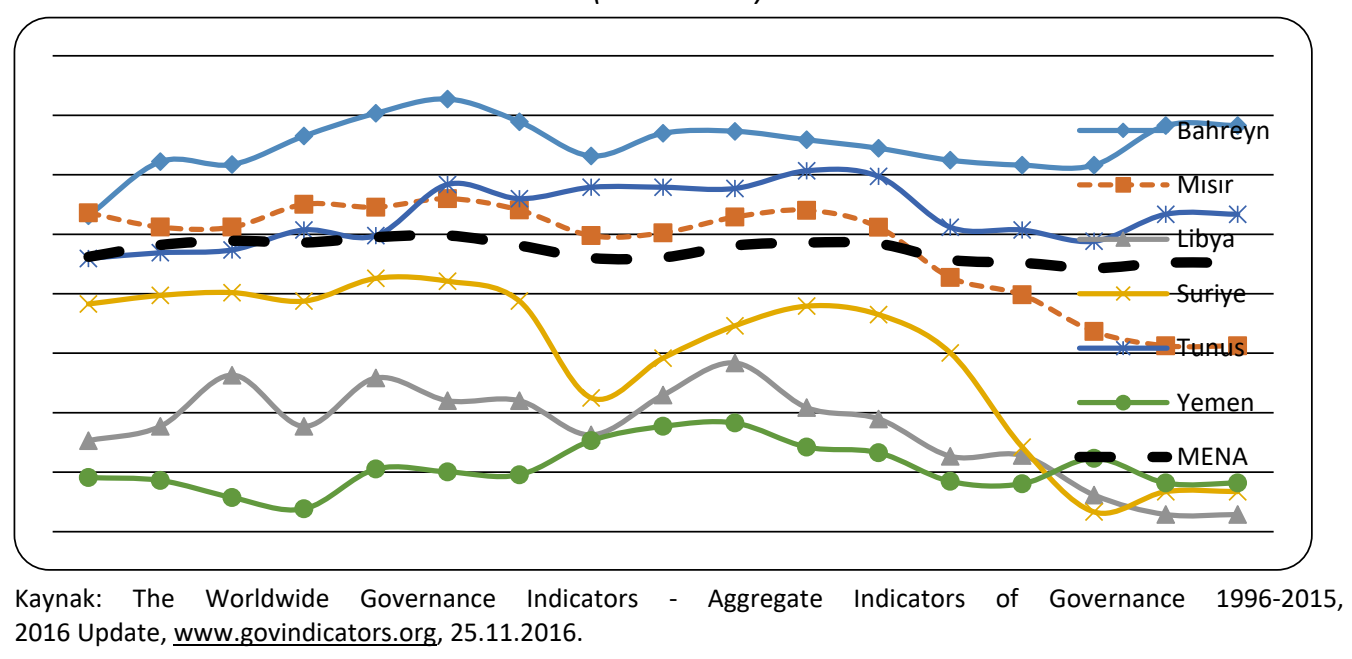

Şekil 12 incelendiğinde; ifade özgürlüğü ve katılımcılık, siyasal istikrasızlık ve şiddetsizlik, yolsuzluk göstergeleriyle de bağlantılı olarak kapsayıcı ve sürdürülebilir bir kurumsal altyapısı bulunmayan Libya, Suriye ve Yemen'de hukukun üstünlüğü değişkeninin oldukça kötü bir görünüm arz ettiği anlaşımaktadır. Öyle ki, geçiş dönemlerinin karmaşık ortamında anayasal ve yasal düzenlemelerinin tam olarak hayata geçirilememesi, hukuk düzeninin neredeyse tamamen ortadan kalkması, genel olarak parçalı bir görünüm arz eden merkezi yönetimlerin otoritelerinin zayıflaması ya da idari kontrolü tamamen kaybetmeleri gibi sorunlar, bu durumun daha da derinleşmesine sebep olmaktadır.

Bölge ortalamasının üzerinde bir skora sahip olan Mısır'da ise bir taraftan vatandaşların kuralları benimseme ve hukuka uyma hassasiyetlerindeki azalma diğer taraftan ise hukuk sisteminin en önemli unsuru olan adli sistemin işleyişinin yönetim baskısı altında bağımsızlık ve tarafsızlığını yitirmesi sonucunda işbu gösterge özelinde adeta bir çöküş yaşanmıştır.

Bağlantılı diğer göstergeler için de belirttiğimiz gibi, hukukun üstünlüğü parametresinin bölge ortalamasının üzerinde bir seyir takip ettiği Tunus ve Bahreyn'de, Arap isyanları ile birlikte 
belirgin bir düşüş eğilimi görülmektedir. Buna göre lider değiş̧ikliği, yeni bir anayasa ve nispeten sağlıklı bir seçim süreci geçiren Tunus'ta hukukun üstünlüğü göstergesi pozitif bir görünüme kavuşmuştur. Kamulaştırma uygulamalarına seyrek rastlanması ve mülkiyet haklarının nispeten daha yüksek güvence altında olması dolayısıyla yüksek bir skora sahip olan Bahreyn'de ise Arap isyanları sürecinin ortaya çıkarttığı toplumsal hareketlerin önünü almak maksadıyla adil, bağımSız ve etkin bir adli teşkilatın tesis edilmesine yönelik düzenlemeler sayesinde hukukun üstünlüğü göstergesi yukarı yönlü bir ivme kazanmıştır.

\section{Değerlendirme ve Sonuç: Arap İsyanları Sürpriz mi, Değil mi?}

Üç kıtanın kesişim noktasında oldukça stratejik bir yer tutan Ortadoğu bölgesinin yakın tarihi, yaşanan jeopolitik-yapısal değişimlerin etkisiyle ortaya çıkan siyasal ve sosyo-ekonomik sorunlar bütünü ile anılmakta; gerek yöneten gerekse yönetilenler açısından oldukça sancılı geçen bu zaman dilimi Arap İsyanları süreci ile somutlaşmış bulunmaktadır. İşte bu çalışmada, "Arap isyanları süreci Ortadoğu için sürpriz bir durum mu, kaçınılmaz bir son mu?" sorunsalına, nicel veriler ve inter-disipliner bir çerçeve sunan Kurumsal iktisat Okulu perspektifinde cevap aranması hedeflenmiştir.

Kurumsal iktisat Okulu'nun yapıtaşını oluşturan kurum kavramı, toplumsal yaşamda ilişki şekillerini biçimlendiren genel kabul görmüş değerler ve sınırlamalar olarak tanımlanmaktadır. Bu bağlamda gayet geniş bir veri setini temel alan kurumsal perspektif, birçok farklı değişkeni de analiz metoduna dâhil etmek suretiyle modern ekonomi politik kırılmaları açıklamak için kullanılan kritik ve muteber bir araç halini almıştır.

Genel olarak siyasal, ekonomik ve sosyal veçheleri itibarıla tasnif edilen kurumlar, birbirini doğrudan ya da dolaylı olarak etkileyen geçişken yapıları ifade etmekte; kurumsal yapının kapsayıcılık düzeyindeki artış teşvik yapıları/müşevvikler olarak görülmekte ise kurumsal yapının dışlayıcı niteliği ise kısıtlayıcı/engelleyici özellik taşımaktadır. Dolayısıyla veri bilgi düzeyinde $k u-$ ruluşlar/organizasyonlar eliyle kurumsal yapının iyi yönde değiştirilmesi/dönüştürülmesi ve böylece kurumsal kalite seviyesinin yükseltilmesi, sürdürülebilir kalkınma hamlesinin yakalanabilmesi açısından önem arz etmektedir.

Çalışma dahilinde, başta Dünya Bankası tarafından yıllık olarak yayımlanan Dünya Yönetişim Göstergeleri olmak üzere birçok uluslararası kurum, düşünce kuruluşu ve sivil toplum organizasyonu tarafından oluşturulan kapsamlı veri setleri ve düzenli raporlar çerçevesinde dinamik ve mukayeseli bir trend analizi yapılmak suretiyle, kurumsal yapısı itibarıyla hem Ortadoğu'nun küresel sistem içerisindeki yeri, hem de Arap İsyanları sürecinde yönetimlerin devrildiği Tunus, Mısır, Libya ve Yemen ile iç savaşın halen devam ettiği Suriye ve ufak çaplı yönetim değişikliklerine sahne olan Bahreyn'in genel Ortadoğu resmi içerisindeki konumlarının incelenmesi şeklinde bir metot izlenmiştir.

Arap İsyanları'ndan yaklaşık yirmi yıl öncesine uzanan veriler bağlamda, Ortadoğu bölgesinde; özellikle otoriter ve/veya baskıcı yönetimlerin işbaşında olması nedeniyle katılımcı siyasal yapıların bulunmaması ve bağlantılı olarak temel hak ve özgürlüklerin alanının daraltılması, şeffaf ve etkin bir bürokratik mekanizma ve iyi işleyen bir yargı sistemi oluşturulmamış olması nedeniyle güven/itibar algısının düşük, yolsuzluk algısının ise yüksek olduğu; işbu siyasal, sosyal ve ekonomik kurumlara dair zikredilen genel problemler doğrultusunda kurumsal kalite düzeyini ifade eden ortalama skorların da dünya ortalamasının altında seyrettiği anlaşılmıştır.

Yine aynı doğrultuda, Arap İsyanları sürecinin yaşandığı ve çalışmamıza konu olan Tunus, Mısır, Libya, Yemen ve Suriye'nin, zaten dünya ortalamasının altında puanlara sahip olan bölge 
ortalamasının dahi altında skorlara sahip oldukları ve Tunus'ta gerçekleştirilen katılımcı seçimler ve siyasal aktörlerin itidalli tavırlar sergilemesi neticesinde oluşturulan yeni anayasa çerçevesinde temel hak ve özgürlükler bağlamında nispi iyileşmeler yaşanmış ise de bundan hariç diğer ülkelerde ve diğer göstergelerde beklenen düzeyde bir iyileşme ya da düzelme söz konusu olmamıştır. Sadece, doğal kaynak zengini olması hasebiyle küresel rekabet gücü anlamında da diğer ülkelere nazaran bariz rekabet üstünlüğü ve yatırımcı dostu düzenlemeleri bulunan Bahreyn'de, özellikle ekonomik kurumların bölge ortalamasının oldukça üzerinde ve gelişmiş ülkeler seviyesinde seyrettiği görülmüştür.

Bütün bu göstergeler bağlamında, Arap İsyanları sürecinin sürpriz bir gelişme olmadı̆̆ı; fakat ideal kurumsal değişim için sağlam/yeterli zemini de sağlamadığı; diğer bir deyişle Arap İsyanları sürecinde elde edilmesi muhtemel kazanımların, Ortadoğu'nun kronik problemleri karşısında kurumsallaşmakta zorluklar yaşadığı mütalaa edilmektedir.

Nihayet şu husus ifade etmek gerekir ki, Arap İsyanları sürecinin en önemli özelliği, çoğu kez bölgeye yapılacak müdahaleler ile sömürü düzeninin sürdürülmesine dair yeni nesil oryantalist bir araç olarak kullanılan, bölgeyi anlamak noktasında en büyük engellerden birisi olarak ortaya çıkan Ortadoğu Istisnacılığı yaklaşımına önemli bir cevap teşkil etmesidir. Şöyle ki, bölge halklarının katılımcı bir siyasal yapı inşası ve bu bağlamda kapsayıcı bir sosyal ve ekonomik kurumsal yapı geliştirilmesine yönelik taleplerinin, diğer dünya bölgelerinden farklı olduğu iddiasını içeren ve bu doğrultuda, Ortadoğu'nun kalkınması yolunda, genel kabul görmüş evrensel hak ve ilkelerden bağımsız olarak bölgeye özel (ve fakat yanlı ve çoğu zaman gerçekle örtüşmeyen) ajandalar belirleyen paradigma, Arap İsyanları sürecindeki taleplerin gerçekleşip gerçekleşmediği hususundan bağımsız olarak, toplumsal taleplerin fiili olarak dillendirilmesi yoluyla çürütülmüş bulunmaktadır. 


\section{Kaynaklar}

Acemoğlu, Daron ve James A. Robinson (2013). Ulusların Düşüşü - Güç, Zenginlik ve Yoksulluğun Kökenleri. 1. Baskı, Faruk Rasim Velioğlu (çev.), İstanbul: Doğan Kitap, 2013.

Ayhan, Veysel (2006). Imparatorluk Yolu: Petrol Savaşlarının Odağında Ortadoğu. 1. Baskı, Ankara: Nobel Yayınevi. Ayhan, Veysel (2012). Arap Baharı - Isyanlar, Devrimler ve Değişim. 1. Baskı, Bursa: MKM Yayıncılık.

Bilgin, Abdül Rezak (2014). Arap Baharı Sürecinde Orduların Tutumu - Mısır, Libya ve Tunus Örnekleri. 1. Baskı, İstanbul: Birleşik Dağıtım Kitabevi.

BP Statistical Review, 2016 Update, 2017.

Çetin, Tamer (2012). Yeni Kurumsal İktisat. Sosyoloji Konferansları. Sayı: 45, 43-73.

Dursun, Davut (2005). Ortadoğu’nun Ekonomik, Sosyal ve Siyasi Yapı Özellikleri Üzerine Genel Tespitler. Sosyal Siyaset Konferansları Dergisi. Sayı: 50, 1232-1274.

Economist Intelligence Unit (2016). Democracy Index 2015 - Democracy in an Age of Anxiety.

Fraser Enstitüsü (2012). Economic Freedom of the Arab World 2012 Annual Report. Al Ismaily vd. (Ed.). Cairo.

Freedom House (2015). Freedom in the World 2016.

Freedom House (2015). Freedom of Press 2015.

Gana, Nouri. (2014). Tunus. Arap Baharından Kesitler - Yeni Ortadoğu'yu Anlamak. Paul Amar ve Vijay Prashad (drl.), Ömer Can Furtun vd. (çev.), İstanbul: İntifada Yayınları, 19-49.

Hanieh, Adam (2014). Bahreyn. Arap Baharından Kesitler - Yeni Ortadoğu'yu Anlamak. Paul Amar ve Vijay Prashad (drl.), Ömer Can Furtun vd. (çev.), İstanbul: İntifada Yayınları, 99-131.

Hanieh, Adam (2015). İsyanın Kökenleri - Kapitalizmin Ortadoğu'daki Sorunları. 1. Baskı, Ali Toprak (çev.), Ankara: Notabene Yayınları.

Heritage Foundation (2014). 2014 Index of Economic Freedom. Miller, Terry vd. (Ed.). Washington D.C.

Heritage Foundation (2015). 2015 Index of Economic Freedom. Miller, Terry vd. (Ed.). Washington D.C.

Kadri, Ali (2014). Arap İsyanları Öncesinde İç Karartıcı Ekonomik Performans. Yeni Ortadoğu - Arap Dünyasında Protesto ve Devrim. 1. Baskı, Fawaz A. Gerges (ed.), M. İkbal Saylık (çev.), İstanbul: İyidüşün Yayınları, 103-131.

Kaufmann, Daniel, Aart Kraay ve Massimo Mastruzzi (2010). The Worldwide Governance Indicators - Methodology and Analytical Issues. The World Bank Policy Research Working Paper. No: 5430.

North, Douglass C. (2002). Kurumlar, Kurumsal Değişim ve Ekonomik Performans. 1. Baskı, İstanbul: Sabancı Üniversitesi Yayını, 2002.

Okumuş, Fatih (2015). İslami Hareketin Iktidar Deneyimi - Tunus ve Mısır. İstanbul: Mana Yayınları.

Öztürkler, Harun (2012). Tunus Ekonomisinin Genel Özellikleri. Ortadoğu Analiz. Cilt: 4, Sayı: 37, 52-59.

Pierce, Chris (2008). Corporate Governance in the Middle East and North Africa. London: GMB Publishing.

Rafeq, Abdul-Karim (2011). Farklı Bir Güç Dengesi - 18. ve 19. Yüzyılda Avrupa ve Ortadoğu. Ortadoğu Tarihi - Dini, Siyasi, Kültürel ve Ekonomik Perspektiften. 1. Baskı, Youssef M. Choueiri (haz.), Fethi Aytuna (çev.), İstanbul: İnkılâp Yayınları, 273-294.

Richards, Alan ve John Waterbury (1998). A Political Economy of the Middle East. USA: Westview Press.

Sakin, Serdar ve Can Deveci (2011). Ortadoğu Kavramı ve Sınırları Üzerine Bir Değerlendirme. History Studies. ABD ve Büyük Ortadoğu ilişkileri Özel Sayısı, 282-293.

Sinkaya, Bayram (2015). Ortadoğu Siyasetine Giriş: Temel Faktörler, Aktörler ve Dinamikler. Orsam Kaynak. No: 1.

Stansfield, Gareth (2011). Siyasi Yaşam ve Ordu. Ortadoğu Tarihi - Dini, Siyasi, Kültürel ve Ekonomik Perspektiften. 1. Baskı, Youssef M. Choueiri (haz.), Fethi Aytuna (çev.), İstanbul: İnkılâp Yayınları, 423-442.

Uğur, Mehmet (2011). Kurumsal Kalite ve Ekonomik Performans - İtisadın (Yeniden) Siyasallaşması mı?. Iktisat ve Toplum. Sayı: 9, 36-41.

Ünay, Sadık (2013). Kalkınmacı Modernlik - Küresel Entegrasyon ve Ortadoğu Ekonomi Politiği. Birinci Basım, İstanbul: Küre Yayınları.

Vincent, Philippe Droz (2014). Arap Dünyasında Ayaklanmalar ve Geçiş Döneminin Ortasında Ordu. Yeni Ortadoğu Arap Dünyasında Protesto ve Devrim. 1. Baskı, Fawaz A. Gerges (ed.), M. İkbal Saylık (çev.), İstanbul: İyidüşün Yayınları, 211241. 
Eskişehir Osmangazi Üniversitesi iiBF Dergisi

World Bank (2016). The Worldwide Governance Indicators - Aggregate Indicators of Governance 1996-2015, 2016 Update, www.govindicators.org, (25.11.2016).

World Economic Forum (2015). The Global Competitiveness Report 2015-2016. Klaus Schwap vd. (Ed.). Geneva. 